\title{
Characterisation of non-capsulate Haemophilus influenzae by repetitive extragenic palindromic (REP)-PCR
}

\author{
J. ZOE JORDENS \\ Oxford Public Health Laboratory, Level 6/7 John Radcliffe Hospital, Headington, Oxford OX3 9DU
}

\begin{abstract}
The use of repetitive extragenic palindromic (REP)-PCR to characterise non-capsulate Haemophilus influenzae (NCHI) for epidemiological studies was validated by application to four outbreak-associated and three epidemiologically unrelated NCHI strains of the same phenotype which had been well characterised by other methods. The REP-PCR patterns were reproducible and showed the unrelated isolates to be distinguishable from each other, whereas the outbreak-associated isolates were indistinguishable. The results were concordant with those from outer-membrane protein enriched profiles, ribotyping and randomly amplified polymorphic DNA analysis. When applied to six further isolates from two different suspected outbreaks, rapid results were obtained from boiled supernates prepared from one colony and indicated that the isolates in question were not related. REP-PCR provides a rapid method of strain characterisation suitable for NCHI, which is ideal for use in conjunction with other methods.
\end{abstract}

\section{Introduction}

Non-capsulate Haemophilus influenzae (NCHI) is associated with respiratory tract infections and outbreaks of infection have been reported [1,2]. NCHI is now also recognised as an important cause of invasive disease $[3,4]$. NCHI strains are extremely diverse and there is no universally accepted typing method for epidemiological investigations. Outer-membrane protein (OMP) analysis and ribotyping are useful but labour intensive and time-consuming techniques [5]. PCR-based methods should provide more rapid results, enabling timely infection control procedures to be implemented. The results from randomly amplified polymorphic DNA (RAPD) analysis were shown to be concordant with OMP analysis and ribotyping [5], but the reproducibility of RAPD patterns is questionable as relatively low annealing temperatures that allow mismatches and a degree of non-specific binding of primer to template are used. Therefore, target-specific PCRbased methods that use higher annealing temperatures are preferable to RAPD. PCR-based ribotyping, which detects variation in the length and sequence of spacer regions within rDNA loci, has been applied success-

Received 19 Dec. 1997; accepted 30 March 1998.

Present address: Department of Molecular Microbiology, University of Southampton, Level C South Block, Southampton General Hospital, Tremona Road, Southampton SO16 6YD, UK. fully to the characterisation of some bacterial species [6], but the rDNA loci in NCHI have been shown to be extremely conserved and unsuitable for this purpose [7].

Amplification of variable genomic DNA between adjacent copies of conserved sequences - repetitive extragenic palindromic (REP) or enterobacterial repetitive intergenic consensus (ERIC) sequences distributed throughout the genome has been shown to discriminate within and between bacterial species [8]. Inter-REP amplification has been applied successfully to epidemiological studies of a wide range of bacterial species including methicillin-resistant Staphylococcus aureus (MRSA) [9] and Streptococcus pneumoniae [10]. Van Belkum et al. amplified interERIC DNA from NCHI and showed the results to be concordant with OMP analysis [11]. However, these studies required relatively large numbers of organisms and lengthy DNA extraction procedures that are complex and too time-consuming for routine clinical laboratories. Simple, rapid methods of target DNA preparation are necessary for strain characterisation to be undertaken readily by hospital-based laboratories.

The present study determined the suitability of interREP PCR for the characterisation of NCHI by studying isolates which had been well characterised epidemiologically and by OMP analysis, ribotyping and RAPD. The use of simple boiled supernates as 
target DNA was also investigated and the technique was applied to two putative outbreaks of respiratory infection.

\section{Materials and methods}

The details of the bacterial isolates studied are given in Table 1. Isolates A1-A7 were characterised in a previous study [5]. All isolates were biotyped by previously described methods [12] and their susceptibilities to ampicillin, chloramphenicol, cefotaxime, trimethoprim, rifampicin and tetracycline were determined by disk diffusion in the PHLS Haemophilus Reference Laboratory (HRL). Epidemiologically unrelated isolates with the same susceptibility and biotype as the suspected outbreak strain were selected from the HRL database and included for comparison. This was done to help exclude the possibility that indistinguishable isolates were representatives of a common clone rather than epidemiologically related isolates of the same strain.

Target DNA was prepared from overnight cultures by extraction with guanidium thiocyanate and precipitation with isopropanol as described previously [5] and DNA concentration was determined by absorbance at $260 \mathrm{~nm}$. Boiled supernates were prepared from one colony as described previously [5]. Amplification reactions, in a total volume of $25 \mu \mathrm{l}$, contained $25-$ $50 \mathrm{pmol}$ of each primer (REP1R-Dt and REP2-Dt) $[8,13], 250 \mu \mathrm{M}$ of each dNTP, $1 \mathrm{U}$ of Taq polymerase (Advanced Biotechnologies, Leatherhead, Surrey), $1 \times$ buffer (provided with the polymerase and containing $2 \mathrm{mM}\left(\mathrm{NH}_{4}\right)_{2} \mathrm{SO}_{4}, 75 \mathrm{mM}$ Tris-Cl, $\mathrm{pH} 9.0$, Tween $200.1 \%, 1.5 \mathrm{mM} \mathrm{MgCl}_{2}$ ), and $100-200 \mathrm{ng}$ of target DNA (or $1 \mu \mathrm{l}$ of boiled supernate). The PCR thermocycle conditions comprised $7 \mathrm{~min}$ at $94^{\circ} \mathrm{C}$ followed by
32 cycles of $1 \mathrm{~min}$ at $94^{\circ} \mathrm{C}, 1 \mathrm{~min}$ at $40^{\circ} \mathrm{C}$ and $8 \mathrm{~min}$ at $72^{\circ} \mathrm{C}$ with a final extension period of $16 \mathrm{~min}$ at $72^{\circ} \mathrm{C}$. A reagent blank (negative control) containing all reagents except target DNA was included with each batch. Products were separated by electrophoresis in agarose $1.6 \%$ gels in Tris-borate EDTA buffer $(89 \mathrm{~mm}$ Tris- $\mathrm{Cl}, 89 \mathrm{~mm}$ borate, $2 \mathrm{mM}$ EDTA, $\mathrm{pH} 8.3$ ) containing ethidium bromide $1 \mu \mathrm{g} / \mathrm{ml}$ and photographed under UV light.

\section{Results}

Both purified DNA and boiled supernates from the initial seven isolates (Table 1, A1-A7) were repeatedly subjected to REP-PCR. For each extraction method, the patterns obtained on different days were indistinguishable. The patterns resulting from the different extraction methods were essentially the same, although some of the larger DNA products $(>1 \mathrm{~kb})$ were sometimes missing from the boiled supernate preparations, generally when more organisms had been emulsified or when the supernates had been stored at $-20^{\circ} \mathrm{C}$. The three epidemiologically unrelated strains gave different patterns (Fig. 1a, tracks 2-4), although two of the unrelated controls (isolates A2 and A3) gave similar, but distinguishable, patterns (Fig. 1a, tracks 3 and 4). The outbreak-associated isolates gave indistinguishable patterns (Fig. 1a, tracks 5-8).

For the isolates from the suspected outbreaks at hospitals B and C, boiled supernates were prepared and used on the same day. The three isolates from hospital B all gave clearly different patterns (Fig. 1b, tracks 1-3), indicating that they were unrelated; isolate B3 had a different biotype from the other two isolates (Table 1). Interestingly, two of the controls (B5 and B6) were indistinguishable, suggest-

Table 1. Characteristics of isolates used in the present study

\begin{tabular}{|c|c|c|c|c|}
\hline Isolate & Source & Biotype & $\begin{array}{l}\text { Antibiotic } \\
\text { susceptibility }\end{array}$ & $\begin{array}{l}\text { REP-PCR } \\
\text { patterns* }\end{array}$ \\
\hline \multicolumn{5}{|c|}{ Previously characterised isolates from hospital A } \\
\hline Al & Control & IV & Fully susceptible & $A(a, 1, i)$ \\
\hline A2 & Control & IV & Fully susceptible & $\mathrm{B}(\mathrm{b}, 2, \mathrm{ii})$ \\
\hline A3 & Control & IV & Fully susceptible & $\mathrm{C}(\mathrm{c}, 3, \mathrm{iii})$ \\
\hline $\mathrm{A} 4-\mathrm{A} 7$ & Outbreak & IV & Fully susceptible & $\mathrm{D}(\mathrm{d}, 4, \mathrm{iv})$ \\
\hline \multicolumn{5}{|c|}{ Suspected outbreak at hospital B } \\
\hline $\mathrm{B} 1$ & Outbreak? & II & Fully susceptible & $\mathrm{E}$ \\
\hline B2 & Outbreak? & II & Fully susceptible & $\mathrm{F}$ \\
\hline B3 & Outbreak? & III & Fully susceptible & $\mathrm{G}$ \\
\hline B4 & Control & II & Fully susceptible & $\mathrm{H}$ \\
\hline B5 & Control & II & Fully susceptible & I \\
\hline B6 & Control & II & Fully susceptible & I \\
\hline \multicolumn{5}{|c|}{ Suspected outbreak at hospital C } \\
\hline $\mathrm{C} 1$ & Outbreak? & I & Fully susceptible & $\mathrm{J}$ \\
\hline $\mathrm{C} 2$ & Outbreak? & I & Trimethoprim resistant & $\mathrm{H}$ \\
\hline $\mathrm{C} 3$ & Outbreak? & II & Fully susceptible & $\mathrm{K}$ \\
\hline $\mathrm{C} 4$ & Control & $\mathrm{I}$ & Fully susceptible & $\mathrm{L}$ \\
\hline $\mathrm{C} 5$ & Control & I & Fully susceptible & M \\
\hline C6 & Control & I & Fully susceptible & $\mathrm{N}$ \\
\hline
\end{tabular}

${ }^{*}$ Lower case letters, arabic numerals and roman numerals represent OMP, ribotyping and RAPD patterns, respectively, determined in reference [5]. 
a

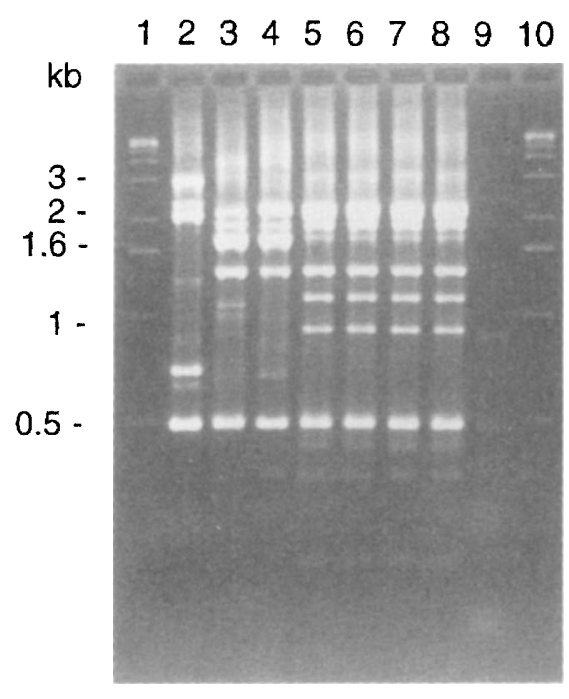

b

$\begin{array}{lllllllllllllll}1 & 2 & 3 & 4 & 5 & 6 & 7 & 8 & 9 & 10 & 11 & 12 & 13 & 14\end{array}$

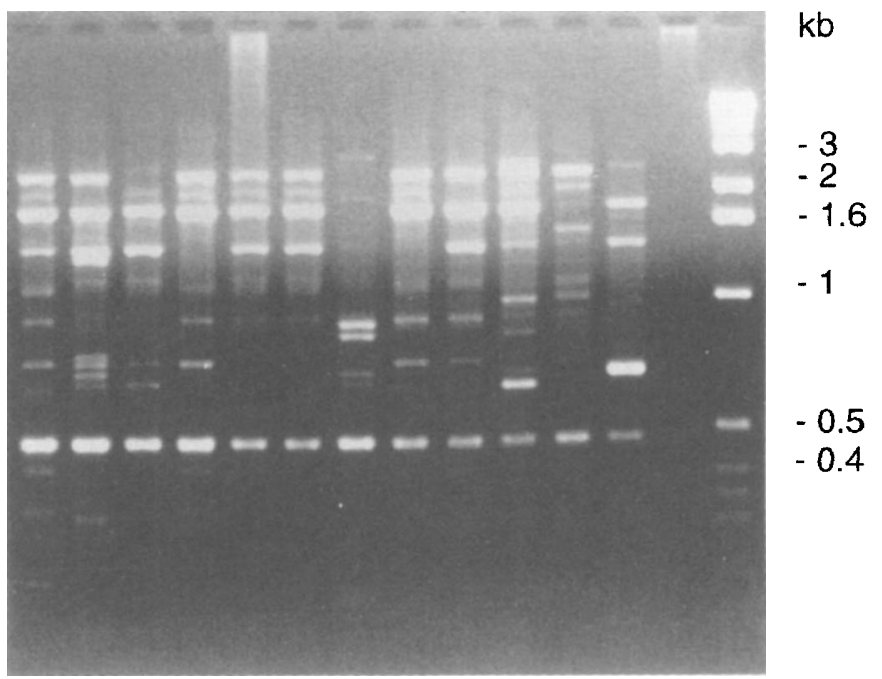

Fig. 1. (a) REP-PCR patterns of isolates A1-A7 with purified target DNA. Lanes 1 and 10, molecular size marker (1$\mathrm{kb}$ ladder, Life Technologies, Paisley); 2-8, correspond to isolates A1-A7, respectively (Table 1); 9, reagent blank. (b) REP-PCR patterns of isolates from suspected oubreaks compared with epidemiologically unrelated controls with boiled supernates as target. Lanes 1-6, correspond to isolates B1-B6; 7-12, correspond to isolates C1-C6 (Table 1); 13, reagent blank; 14, molecular size marker.

ing that a clone (or common type) might be present within this phenotype (Fig. 1b, tracks 5 and 6). The three isolates from hospital $\mathrm{C}$ also gave readily distinguishable REP-PCR patterns; these could be distinguished also on the basis of phenotype (Fig. 1b, tracks 7-9; Table 1). The unrelated strains gave different patterns (Fig. 1b, tracks 10-12). Isolates B4 and $\mathrm{C} 2$ gave indistinguishable patterns (Fig. 1b, tracks 4 and 8), although these isolates had different biotypes and antibiotic susceptibilities (Table 1) which indicated that they were different strains. In general, no products were detected in the negative controls, although occasionally very faint bands were seen; these did not interfere with the REP-PCR patterns (Fig. 1a, track 9).

\section{Discussion}

PCR-based methods of strain characterisation provide a potentially simple, rapid and effective means of distinguishing strains in outbreaks. RAPD analysis initially appeared to provide such a method, but reproducibility problems have rendered the method virtually obsolete. Although, in this laboratory, RAPD analysis of NCHI performed several times within a short time period (several weeks or a few months at most) resulted in the same patterns for the same isolates, different patterns were obtained when the same isolates were resuscitated from stocks stored at $-70^{\circ} \mathrm{C} 1$ year later. Different sources of thermostable polymerase and thermal cyclers have been shown to affect banding patterns [14] but, even when these are standardised, variation in patterns may occur. Variation in DNA concentration has been shown to significantly affect the reproducibility of RAPD patterns [15]. PCRribotyping and restriction analysis of rDNA amplification products failed to distinguish unrelated strains [7]. Amplification of inter-repeat element genomic DNA offers an alternative PCR-based approach that uses higher and more stringent temperatures for annealing than RAPD and hence should be more reproducible.

The present study validated REP-PCR for the characterisation of NCHI by application of the method to well characterised strains. The loss of the larger bands in patterns obtained from boiled supernates may be caused by target DNA degradation in the crude preparation. Alternatively, it may be a result of much lower target DNA concentration, as suggested for RAPD [15]. However, the similarity of patterns for isolates A2 and A3 (these differed only in the presence of faint small bands and the intensity of a large band) which had given clearly distinguishable OMP, ribotyping and RAPD patterns (each technique showed several distinct band differences between these strains), and indistinguishable patterns for strains B4 and $\mathrm{C} 2$, distinguishable by biotyping and antibiotic susceptibility, underlines the need to use at least two different typing methods in outbreak investigations, especially when isolates suspected to be related epidemiologically are indistinguishable. Results from molecular typing investigations should be interpreted in conjunction with other laboratory results and epidemiological information. The REP-PCR patterns are a reflection of the distribution of REP-like sequences around the genome, but the biological significance of this, if any, is unknown. As this 
genotyping method is almost certainly unrelated to other methods and is reproducible, technically simple and can provide a rapid result, it is ideal to use in combination with more established methods in outbreak investigations.

Boiled supernates enabled rapid characterisation of isolates from suspected outbreaks, providing a result on the same day as receipt of isolates. Such simple methods of target preparation are adequate for many gram-negative bacteria, but gram-positive organisms often require more complex extraction procedures $[9,10]$. The ability to confirm (or refute) the existence of an outbreak on the same day enables cross-infection precautions to be lifted or continued as appropriate with a minimum waste of resources. The use of REPPCR, possibly together with another, independent target-specific PCR fingerprinting method such as inter-ERIC PCR, should enable any laboratory with PCR technology to characterise NCHI, as well as a range of other bacterial species associated with nosocomial infections.

J.Z.J. thanks Dr Mary Slack and Miss Helen Azzopardi of the Haemophilus Reference Laboratory (HRL) for biotyping and antibiotic susceptibility data, and all contributors of strains to the HRL.

\section{References}

1. Anderson JR, Smith MD, Kibbler CC, Holton J, Scott GM. A nosocomial outbreak due to non-encapsulated Haemophilus influenzae: analysis of plasmids coding for antibiotic resistance. $J$ Hosp Infect 1994; 27: 17-27.

2. Goetz MB, O'Brien H, Musser JM, Ward JI. Nosocomial transmission of disease caused by nontypeable strains of Haemophilus influenzae. Am J Med 1994; 96: 342-347.

3. Murphy TF. Invasive $H$. influenzae infections in adults?
Another clinical pearl down the drain! Infect Dis Clin Pract 1994; 3: 41-43.

4. Deulofeu F, Nava JM, Bella F et al. Prospective epidemiological study of invasive Haemophilus influenzae disease in adults. Eur J Clin Microbiol Infect Dis 1994; 13: 633-638.

5. Jordens JZ, Leaves NI, Anderson EC, Slack MPE. Polymerase chain reaction-based strain characterization of noncapsulate Haemophilus influenzae. J Clin Microbiol 1993; 31: 29812987.

6. Kostman JR, Alden MB, Mair M, Edlind TD, LiPuma JJ, Stull TL. A universal approach to bacterial molecular epidemiology by polymerase chain reaction ribotyping. J Infect Dis 1995; 171: 204-208.

7. Jordens JZ, Leaves NI. Source of variation detected in ribotyping patterns of Haemophilus infuenzae: comparison of traditional ribotyping, PCR-ribotyping and $\mathrm{rDNA}$ restriction analysis. J Med Microbiol 1997; 46: 763--772.

8. Versalovic J, Koeuth T, Lupski JR. Distribution of repetitive DNA sequences in eubacteria and application to fingerprinting of bacterial genomes. Nucleic Acids Res 1991; 19: 6823-6831.

9. Lessing MPA, Jordens JZ, Bowler ICJ. Molecular epidemiology of a multiple strain outbreak of methicillin-resistant Staphylococcus aureus amongst patients and staff. J Hosp Infect 1995; 31: $253-260$.

10. Jordens JZ, Paul J, Bates J, Beaumont C, Kimari J, Gilks C. Characterisation of Streptococcus pneumoniae from human immunodeficiency virus-seropositive patients with acute and recurrent pneumonia. J Infect Dis 1995; 172: 983-987.

11. van Belkum A, Duim B, Regelink A, Moller L, Quint W, van Alphen L. Genomic DNA fingerprinting of clinical Haemophilus influenzae isolates by polymerase chain reaction amplification: comparison with major outer-membrane protein and restriction fragment length polymorphisrn analysis. $J \mathrm{Med}$ Microbiol 1994; 41: 63-68.

12. Kilian M. A taxonomic study of the genus Haemophilus, with the proposal of a new species. J Gen Microbiol 1976; 93: 9-62.

13. Versalovic J, Kapur V, Mason EO et al. Penicillin-resistant Streptococcus pneumoniae strains recovered in Houston: identification and molecular characterization of multiple clones. $J$ Infect Dis 1993; 167: 850-856.

14. Meunier J-R, Grimont PAD. Factors affecting reproducibility of random amplified polymorphic DNA fingerprinting. Res Microbiol 1993; 144: 373-379.

15. Davin-Regli A, Abed Y, Charrel RN, Bollet C, de Micco P. Variations in DNA concentrations significantly affect the reproducibility of RAPD fingerprint patterns. Res Microbiol 1995; 146: 561-568. 